DOI: https://doi.org/10.34069/AI/2021.46.10.21

How to Cite:

Prytula, A., Lutsyk, V., Sviatoshniuk, A., Tkalia, O., Kalachenkova, K. (2021). Cryptocurrency in transnational offenses: criminal and civil legal aspects. Amazonia Investiga, 10(46), 209-216. https://doi.org/10.34069/AI/2021.46.10.21

\title{
Cryptocurrency in transnational offenses: criminal and civil legal aspects
}

\section{Криптовалюта у транснаціональних правопорушеннях: кримінально-правовий та цивільно-правовий аспект}

Received: October 10, 2021

Accepted: November 3, 2021

\author{
Written by: \\ Anatolii Prytula ${ }^{80}$ \\ https://orcid.org/0000-0001-8478-4583 \\ Vasyl Lutsyk ${ }^{81}$ \\ https://orcid.org/0000-0002-0974-4714 \\ Aryna Sviatoshniuk ${ }^{82}$ \\ https://orcid.org/0000-0001-7728-3190 \\ Olena Tkalia $^{83}$ \\ https://orcid.org/0000-0003-4924-237X \\ Kateryna Kalachenkova ${ }^{84}$ \\ https://orcid.org/0000-0003-0720-2476
}

\begin{abstract}
The emergence of digital technologies contributed to the emergence and rapid development of digital commerce, and at the same time, the number of electronic payments, the use of digital and virtual currencies increased. The article presents an analysis of the legal nature of such a financial instrument as cryptocurrency, characterizes the distinctive features, highlights the advantages and disadvantages. The purpose of the work is to consider the regulatory legal position of cryptocurrency in the modern world, to highlight the legal practice in cases of the circulation of cryptocurrency, to study the role of cryptocurrency in transnational offenses, to explore possible options for combating cybercrime, which is carried out using the use of cryptocurrency. The methodology of the work is represented by a set of methods and techniques, operations that are used to study the topic and achieve the set goal, namely: hermeneutic, historical, extrapolation, comparative-legal, comparison and generalization, analysis,
\end{abstract}

\begin{abstract}
Анотація
Поява цифрових технологій сприяла процесу зародження та стрімкого розвитку цифрової комерції та, разом 3 цим, підвищилася кількість проведення електронних платежів, використання цифрових та віртуальних валют. У статті надано аналіз правової природи такого фінансового інструменту, як криптовалюта, охарактеризовано відмінні риси, виділено переваги та недоліки. Мета роботи - розглянути нормативно-правове становище криптовалюти у світі, висвітлити юридичну практику у справах звернення криптовалюти, вивчити роль криптовалюти в транснаціональних правопорушеннях, дослідити можливі варіанти боротьби 3 кіберзлочинністю, які здійснюються 3 допомогою криптовалюти. Методологія роботи: герменевтичний та історичний метод, метод естраполяції, порівняльно-правової, зіставлення та узагальнення, аналіз, синтез, дедукція. Результати роботи: зроблено висновок, що у сьогоднішніх реаліях відсутне уніфіковане міжнародне нормативно-правове
\end{abstract}

\footnotetext{
${ }^{80}$ Doctor of Science of Law, Professor, International Humanitarian University, Ukraine.

${ }^{81} \mathrm{Ph} . \mathrm{D}$., Associate Professor, Head of the Department for the Protection of Whistleblowers and Corruption Reporting of the Department for the Prevention and Detection of Corruption, National Agency for the Prevention of Corruption, Ukraine.

${ }^{82}$ Ph.D., Associate Professor of the Department of Civil Law Disciplines of the Economics and Law Faculty of Odessa I. I. Mechnikov National University ", Ukraine.

${ }^{83}$ Ph.D., Associate Professor of the Department of Constitutional and Administrative law and process of the Petro Mohyla Black Sea National University, Ukraine.

${ }^{84}$ Ph.D., Associate Professor of the Department of Economic and Administrative Law, Vasyl' Stus Donetsk National University, Ukraine.
} 
synthesis, deduction. Results of the work: in today's reality there is no unified international legal regulation of cryptocurrency, which complicates the prevention and fight against transnational offenses, the means or subject of which are cryptocurrencies and mining.

Keywords: cryptocurrency, mining, legislative regulation, cryptocrime, transnational crime.

\section{Introduction}

Today there is a clear need to study the conceptual content and legal regulation of cryptocurrency, bitcoin, mining, to study in detail the legal field of cryptocurrency in various states, to analyze the objective increase in the number of offenses carried out with the help of digital money and to develop methods to prevent the implementation of illegal acts using cryptocurrency.

In the world community, there is the use of cryptocurrency in such illegal acts as legalization (money laundering) obtained by criminal means, sale, and purchase of drugs, psychotropic substances, firearms, distribution of child pornography, smuggling transactions, extortion, fraud, theft, and corruption. The relevance of the topic is since the above types of crimes have the character of transnationality and increased public danger and, therefore, require the development of methods and methods to counter these offenses at the international level, through consolidation and common, well-coordinated work. A unified understanding of the civil law nature of cryptocurrency is obviously necessary for the possibility of qualifying crimes in criminal law. In 2019, the International Monetary Fund presented the results of a study of cryptocurrencies on its official website and officially confirmed that cryptocurrencies are already direct competitors of banks. Digital currency has gained immense popularity in the USA, Canada, Japan, Switzerland, Germany, Great Britain, and several other highly developed countries. For example, in Japan, since April 2017, cryptocurrency has received the status of a means of payment. In the US, cryptocurrency is a decentralized virtual currency. In Canada, the implementation of any transactions with cryptocurrency is necessarily taxed as a barter transaction. If citizens want to sell cryptocurrency, then they pay income tax or capital gains. In Romania, Pakistan, Bolivia, and Ecuador, the use of cryptocurrencies is prohibited. At the international level, the legal status of cryptocurrency has not been finally регулювання криптовалюти, що ускладнює попередження та боротьбу 3 транснаціональними правопорушеннями, засіб чи предмет яких - криптовалюти та майнінг.

Ключові слова: криптовалюта, майнінг, законодавче криптозлочинність, регулювання, злочинність.

транснаціональна

determined. There is no unified approach to the criminal and civil legal aspects of this phenomenon; theory and judicial practice have not developed a single regulation either. And the reality is that no matter what position the jurisprudence takes, cryptocurrency is already in international circulation.

The purpose of the work is to consider the regulatory legal position of cryptocurrency in the modern world, to analyze the available legal levers of cryptocurrency management, to highlight the legal practice in cases of cryptocurrency circulation, to study the role of cryptocurrency in transnational offenses, to reveal in detail the criminal and civil legal aspect of this area, analyze the reasons for the high popularity of the use of cryptocurrency in transnational offenses, explore possible options for combating cybercrime, which is carried out using the use of cryptocurrency. The object of the research is the content of the concept and the legal status of the cryptocurrency. The subject of the research is cryptocurrency in transnational offenses: criminal and civil aspects. The conclusion is made about the civil law multidimensionality of the research object. The author presents that cryptocurrency can act as a means and subject of transnational offenses, in this regard, a specific type of crime can be distinguished in criminal law - cryptocrime.

\section{Theoretical Framework or Literature Review}

The economic and legal phenomenon of cryptocurrency is a new and relevant topic today. The concept of cryptocurrency, its legal status in individual states and at the international level, the development of legislation to regulate the circulation of cryptographic currency are all topics of scientific research by modern scientists. Thus, Zhelyuk and Brechko (2016) define cryptocurrency as a stable, universal instrument for global financial payments and, at the same time, a financial instrument with a high level of capitalization. 
Moreover, Soslovsky and Kosovsky (2016) consider cryptocurrency as a means of payment that has no material form but exists in the form of a program code using cryptographic protection methods, the release, and accounting of which is decentralized and known to the participants in the settlements.

The cryptocurrency does not have an issuer or other body that is called upon to control its turnover. In this context, Rasheva and Chirkova (2017) draw attention to the fact that during payments, for example, only the payer and the recipient take part in the Bitcoin system. In this relationship, there is no contractual relationship with the operator (issuer) of electronic money due to its absence. This provides additional opportunities for participants in transactions since no one can seize, suspend account transactions, cancel a payment.

Skripnik (2018) notes that in some countries, de facto, there has been a turnover of various types of cryptocurrencies for several years, although virtual money in these countries is not recognized as an object of civil rights, is not considered a means of payment, but is the subject of numerous and not always legal transactions. In this situation, the legal regulation of cryptocurrency turnover contributes to the reduction of illegal transactions and increases the level of protection of the subjects - participants in this turnover, their control, and taxation.

Further, Kaznacheeva and Dorosh (2020), in their scientific works, demonstrate an analysis of the disadvantages and advantages of cryptocurrency. Advantages: the open code of the algorithm provides everyone who wants to mine cryptocurrency, the anonymity of transactions, the absence of a single issuer, no control over transactions and payments, the system is completely decentralized, the impossibility of counterfeiting. Disadvantages: due to the lack of regulatory mechanisms, there is no guarantee of the preservation of electronic wallets, a high level of exchange rate variability, the inability to resume access to the wallet in the event of a password loss, over time, mining ceases to be profitable for individual users. It is also worth noting that some of the advantages are also disadvantages at the same time.

Solodovnikov, together with Bardina (2019), rightly points out that legislators must strike a balance between the need to get rid of the legal vacuum and avoid harsh interference with the status and circulation of cryptocurrency. Overregulation will negatively affect the development of the digital economy and the operation of new financial technologies.

Some theoretical scientists and practitioners (comparing cryptocurrency with fiat money) are divided into two groups. Most adhere to the position that cryptocurrency is electronic money, since:

- firstly, the creator of bitcoin himself Satoshi Nakamoto called bitcoin "electronic cash";

- secondly, cryptocurrencies are used as a means of payment (for example, they can be used for payments in such online retailers like Overstock and Amazon, as well as in the Microsoft Store), and;

- thirdly, it is possible to exchange cryptocurrency for real money in specialized exchangers.

Arguments "against" the fact that the cryptocurrency has a monetary nature, namely, the cryptocurrency is not provided by the issuer, the exchange rate is unstable (and high volatility makes it impractical to denominate goods and services in cryptocurrency), low speed and complexity of some transactions (Grigoriev, Nurislamova, \& Nurislamova, 2021).

For the first time, Europol spoke about the presence of cryptocurrency in the criminal world in its report in 2015. Then, it was stated that the digital currency gained the greatest distribution in the field of corruption crimes, in the sale of drugs, psychoactive substances, pornography, weapons, in the laundering of illegally obtained proceeds. These illegal acts are often carried out using the resources of the illegal Internet (darknet) (Vc.ru, 2018).

Detailed consideration of the civil status of cryptocurrency, the criminogenic risks of cryptocurrency, its use as a means and subject of offenses, the activities of law enforcement agencies to the prevention and fight against crime, which is associated with the use of virtual money, all these are socially major topics, which should be continuously monitored, investigated, studied and analyzed.

\section{Methodology}

The work uses the following methods of scientific knowledge: hermeneutic, historical, extrapolation, comparative-legal, comparison and generalization, analysis, synthesis, deduction. 
The hermeneutic method is applied for a detailed study of the conceptual apparatus on a given topic. Thanks to this method, the meaning of concepts, definitions, definitions, and categories that are used by theorists and practitioners in the field of digital technologies in general and cryptocurrencies, in particular, is learned.

The comparative legal method was utilized during the knowledge of the legal regulation of cryptocurrency in different countries and at different time periods. Revealing the similarity of legal positions and regulatory levers makes it possible to determine patterns and trends.

Analysis of the legal essence of cryptocurrency, by highlighting characteristic features and properties, studying them separately as part of a whole. A correctly conducted analysis is a serious guarantee of the consistency of the presentation of the research material. The application of the deductive method of cognition is necessary when the facts themselves do not explain the causes of the phenomenon. The deduction helps to develop a specific version of the causal series that explains the consequences.

The analysis is necessarily carried out in unity with the use of synthesis, since it is essential, having studied the individual properties of the phenomenon, to consider them as a system, that is, a set of interrelated elements that generate each other and are necessarily interconnected, interdependent.

\section{Results and Discussion}

One of the main needs for the development of legal regulation of cryptocurrency is the rapid increase in the number of crimes that are carried out not only concerning digital currency but also with its use as a tool. The growth of such crimes is facilitated by the fact that transactions using cryptocurrencies are provided with a high level of anonymity, and law enforcement agencies cannot track the locations of transactions.

The Bitcoin payment system was created in 2009 , and the global popularity of crypto money began to grow rapidly in July 2013 and, at the same time, there was concern that cryptocurrency could become an element of crime since every owner of an electronic wallet is a bank, and many computers with wallets around the world form a huge bank, this system is fully automatic, decentralized (no internal and external control), works around the clock.
International law enforcement agencies, in particular Europol, analyzing the level and specifics of modern crime, states that cryptocurrency is especially popular in the field of legalization (laundering) of proceeds from crime, in the field of trafficking in persons, drugs, psychotropic substances, counterfeit money, and documents, in the field of financing of international terrorism, the number of crimes against property, namely, fraud with cryptocurrencies and their investment, is increasing.

International organizations carry out significant activities in the prevention and disclosure of criminal acts using cryptocurrency. In particular, this is the preparation of methodological recommendations, round tables, symposia, conferences, meetings, and training courses, seminars, this is the creation of special law enforcement agencies, rapid response groups, etc. However, it should be noted that preventing and combating crime by using cryptocurrency is complicated by the high level of anonymity of transactions, the rapid development of digital technologies, and the lack of unity in defining the legal essence of cryptocurrency. The existing legal framework in the field of cybercrime does not fully correspond to modern realities. The world community is obliged to consolidate and develop uniform rules for the circulation of cryptocurrency both for its daily use and for combating crime, with its criminal turnover. However, it should be recognized that regardless of the civil law status of the cryptocurrency and regardless of the regulation of the civil legal circulation of the cryptocurrency, this type of digital money is already capable of acting as a subject or means of committing a crime.

The existing legal framework in the field of cybercrime does not fully correspond to modern realities. The world community is obliged to consolidate and develop uniform rules for the circulation of cryptocurrency both for its daily use and for combating crime, with its criminal turnover. However, it should be recognized, that regardless of the civil law status of the cryptocurrency and regardless of the regulation of the civil legal circulation of the cryptocurrency, this type of digital money is already capable of acting as a subject or means of committing a crime.

In 2011, Forbes magazine first published an article about bitcoin, where it was called cryptocurrency. Prior to this, the term "electronic cash" was used. Some classify cryptocurrency as a "virtual currency" and call it an innovative 


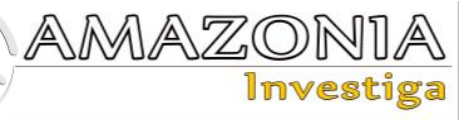

payment network and a new type of money. Others deny the involvement of cryptocurrency in money and call it a "digital asset".

One of the first to develop and publish a report on cryptocurrency, proposed a definition and procedure for using cryptocurrency, was the European Central Bank. After the hack of Mt.Gox, which led to the loss of more than $\$ 350$ million in bitcoins, the European Central Bank prepared a report in which it outlined its position on cryptocurrency, including documenting that cryptocurrency as a "virtual currency is a digital representation of value, not issued by a central bank or credit institution, which in some cases can be used as an alternative to money" and can function as a medium of exchange or unit of account, but not a store of value (Pinkevich, \& Smolyaninov, 2021).

Considering the civil nature of cryptocurrency, it should be noted, that the legalization of cryptocurrency in some countries allows people to carry out transactions in the field of trade using cryptocurrency, exchange them for fiat money, sell on exchanges, etc. In the US, cryptocurrency is regulated at the federal and state levels. Today, the United States has the largest digital currency market in the world. Regulation differs from state to state and is considered property, commodity, or even money. Bitcoin transactions are taxed in the US. In the state of New York, a special license is issued to conduct a cryptocurrency business, which has become the object of criticism from large cryptocurrency companies and the reason for leaving the state. In Washington, DC, cryptocurrency is the object of remittances. Companies are only allowed to make money transfers to residents of Washington if they hold a Washington Money Transfer License (Vc.ru, 2018). The leitmotif of cryptocurrency regulation in Japan is "not to prohibit, but to cooperate". There, financial services agencies are allowed to regulate and issue licenses to trade cryptocurrencies. Thanks to some legislative acts, participants are protected from the likelihood of bankruptcy of cryptocurrency exchanges (E-commerce, 2017). In Norway, cryptocurrency is an asset that is subject to capital gains tax.

Taking into account the adoption in Ukraine in the second reading and the direction for signing by the President of the Law of Ukraine "On Virtual Assets", we state that another state is at the stage of legalizing cryptocurrency. Following the bill, cryptocurrency is recognized as an object of civil rights, in particular, an intangible benefit. Separately, it should be noted that the provisions of part seven of Article 4 of the draft law, according to which "virtual assets are not a means of payment on the territory of Ukraine and cannot be exchanged for property (goods), work (services)", is devoid of legal content, and contradicts the norms of the current civil legislation, therefore, it will be inapplicable in practice. So, according to the first part of Article 715 of the Civil Code of Ukraine, under an exchange (barter) agreement, each of the parties undertakes to transfer to the other party one product in exchange for another product. At the same time, the second part of the same article stipulates that each of the parties to the barter agreement is the seller of the goods that he transfers in exchange and the buyer of the goods that he receives in return. Thus, an exchange agreement is, in fact, a combination of two sales and purchase agreements. Consequently, a virtual asset as an object of civil rights can be the subject of a barter agreement (Proposition 3637, 2020).

Notable is the position of the Central Bank of Cyprus "Bitcoin is not illegal, but at the same time neither is it subject to control or regulation". Thus, cryptocurrency management is carried out in accordance with the general rules of civil law. In the course of studying the activities of this country, the activity of accepting payments from a number of educational institutions, in particular the University of Nicosia, was identified, which confirms the presence and use of cryptocurrency as a means of payment. Based on the analysis of the tax legislation in force in Cyprus, it follows that profits from trading in cryptocurrency are not taxed (the rate is $0 \%$ ) since "the Cyprus Tax on profits from trading is shares or other securities including forex or bitcoins is $0 \%$ " (Law \& Trust, 2021a).

The civil status of the cryptocurrency is clearly defined by the Spanish authorities, as the cryptocurrency is designated as an electronic means of payment. Moreover, since 2016, miners have been cleared to register and pay the corresponding taxes.

The Central Bank of Mexico calls cryptocurrency a highly speculative phenomenon and warns of the dangers of investing in it. On the other hand, the Central Bank has equated cryptocurrencies with commodities. However, given that the authorities have extended the same restrictions on cryptocurrency as regarding cash, in practice, in Mexico, the legal status of cryptoassets is equated to the national currency (Law \& Trust, 2021b). 
Thus, it is obvious, that there are different approaches regarding the incorporation of cryptocurrency into legislation and at the international legal level, the concept of cryptocurrency is not unified, and this provision potentially increases the implementation of many transnational offenses.

A group of legal scholars believes that digitalization does not lead to the emergence of a new type of property rights (along with obligations, corporate, exclusive rights) but only determines the digital way of securing already known types of rights (Vasilevskaya, 2019).

Some scientists argue that the difference between the concepts of "currency" and "cryptocurrency" will soon be erased, therefore, the cryptocurrency will be recognized as property, and the rules on currency control will apply to it.

Even taking into account the presence of different polarities regarding the definition of the concept of "cryptocurrency", the following main features stand out: cryptocurrency has the form of a digital code that is generated in accordance with complex mathematical algorithms, that is, falsification is impossible, cryptocurrency is capable of performing the functions of fiat money, namely, acting as a means of payment, exchange, a measure of value, for operations using cryptocurrencies the anonymity of participants is inherent - the network uses cryptographic methods of asymmetric data encryption using public and private keys, transactions with cryptocurrency are recorded in blockchain technology, the rate is set by the market, without reference to any state, high the degree of volatility, the absence of an issuer, the cryptocurrency system is completely closed and decentralized, the rules of operation are established by its participants, the operation of such a network is based on the equality of all participants.

The above is the advantage of the cryptocurrency, but, at the same time, it increases the transnational crime potential, and the absence of legal regulation in whole, in part, or the diversity of approaches, interferes with acting at the international level in a coordinated manner and one direction.

Moreover, the above shows that the supranational properties of cryptocurrencies, prohibitive and restrictive actions within the framework of one state are ineffective and poorly implemented. Exchanges within one state can prohibit the use of cryptocurrencies as a means of payment, but it is almost impossible to prohibit their exchange for cash on international cryptocurrency exchanges. It is unrealistic to prohibit the websites on which the use of cryptocurrencies is proposed since they operate outside the legal framework and are completely anonymous.

The widespread use of cryptocurrency in the world of crime makes it necessary to single out a separate object of research - cryptocrime. This collective term should be understood as a set of illegal acts committed with virtual currency, or with its use.

It seems possible to single out the main types of cryptocrime: financing of terrorism and extremism; theft of funds; fraud; illegal sale of psychoactive substances (narcotic drugs, psychotropic substances, etc.), other prohibited goods, content, or services using the darknet markets; servicing ransomware programs; laundering (legalization) of criminal proceeds. Offenses committed with the use of cryptocurrency are heterogeneous: encroachment on property, crimes in the field of economic activity, crimes against public safety.

Cryptographic offenses are characterized by their transnational and timeless nature. It is important to note that cryptocrimes, unlike economic crimes, lead to digital damage, the investigation of such crimes requires specific electronic evidence and, possibly, after connecting to the appropriate technology of the distributed ledger on which the cryptocurrency operates; in addition, specific measures of a criminal-legal nature can be applied to such crimes, in particular, the confiscation of cryptocurrency and its conversion into state revenue (Dolgieva, 2018).

However, in the international arena, to date, basic documents on joint counteraction to criminal activity using cryptocurrencies have not been adopted. In 2020, UN Secretary-General António Guterres made a proposal that the UN should exploit blockchain and distributed ledger technology (DLT) and recommended that blockchain technology be included among the core technologies used by the UN (Antypov, 2019). The Secretary-General noted that work is already underway with the World Wide Web to examine identifier records on the blockchain to counter trafficking in children. And more recently, the organization launched a blockchain tool that prevents the exploitation of migrant labor in Hong Kong (Cryptonews, 2021). 


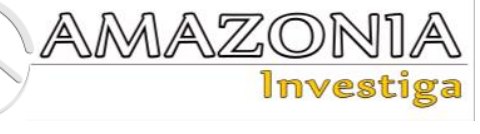

Given the high degree of anonymity of transactions with cryptocurrency, financial, tax, judicial, and law enforcement agencies cannot influence financial transactions involving cryptocurrency (cancel, block, challenge or force them to complete without access to the owner's private key). This creates difficulties in identifying persons who are guilty of illegal activities.

The International Monetary Fund appealed to the world community and called for the global coordination of legal regulation of cryptocurrency, due to the fact that the high degree of its volatility is a serious risk for the investor. The IMF insists on the need for international governance and ongoing supervision of the circulation of cryptocurrencies (Inc., 2018). Also, the IMF, in cooperation with the World Bank, created a training coin "quasicryptocurrency" on its blockchain with limited access for training. Since the technology of the distribution register (blockchain) is rapidly improving, and with its various types of cryptocurrencies are developing, it is necessary to study information about them, the mechanism of their use, and ways of using them for criminal purposes (Ihodi, 2021).

\section{Conclusions}

The advent of cryptocurrency has seriously affected the quantitative indicators and types of criminal acts in the global community. Cryptocurrency has many advantages, which, in turn, also disadvantage since they determine the use of digital money data as a means of committing crimes. Noting the high level of influence of cryptocurrency on transnational crime, which will persist, international organizations need to consolidate and establish a common understanding of the legal status of cryptoassets, take unified measures for the circulation of cryptocurrency, but at the same time leave the possibility of the legitimate use of blockchain technology, including the use of cryptocurrency as a means of preserving savings and means of payment for legitimate goods and services.

\section{Bibliographic references}

Antypov, G. (2019). TECHNOLOGY: Cryptocurrencies open up new horizons in digital finance. CoinSpot, https://coinspot.io/technology/oonkriptovalyuty-otkryvayut-novye-gorizontyv-cifrovyh-finansah
Cryptonews. (2021). The head of the United Nations touts blockchain technology as a critical component of the digital age. https://cryptonews.one/blockchain/glavaorganizacii-obedinennykh-nacijjreklamiruet-tekhnologijublokchejjna-kakvazhnejjshijj-komponent-ehpokhi-cifrovykhtekhnologijj

Dolgieva, M.M. (2018). Cryptocrime as a new type of crime: concept, specificity. YurFak: study law online. https://urfac.ru/?p=805

E-commerce. (2017). Japanese banks will create a national digital currency. https://ecommerce.com.ua/2017/09/\%d1\%8f\%d0\%b f\%d0\%be \%d0\%bd\%d1\%81\%d0\%ba\%d0\%b $8 \% \mathrm{~d} 0 \% \mathrm{~b} 5-$

$\%$ d0\%b1\%d0\%b0\%d0\%bd\%d0\%ba\%d0\%b 8 -

$\%$ d1\%81\%d0\%be\%d0\%b7\%d0\%b4\%d0\%b $0 \% \mathrm{~d} 0 \% \mathrm{~b} 4 \% \mathrm{~d} 1 \% 83 \% \mathrm{~d} 1 \% 82-$

$\% \mathrm{~d} 0 \%$ bd $\%$ d0\%b0\%d1\%86\%d0\%b8\%d0\%b e\%d0\%bd\%d0\%b0\%d0\%bb\%d1\%8c\%d0\% bd $\%$ d $1 \% 83 /$

Grigoriev, V., Nurislamova, N., \& Nurislamova, E. (2021). Functional aspects of cryptocurrency. Russia: Trends and Development Prospects. https://cyberleninka.ru/article/n/funktsionaln ye-aspekty-kriptovalyuty/viewer

Ihodi. (2021). The IMF and the World Bank have released their own cryptocurrency. https://ru.ihodl.com/topnews/2019-0415/mvf-i-vsemirnyj-bank-vypustilisobstvennuyukriptovalyutu

Inc. (2018). IMF head: regulation of cryptocurrency transactions is inevitable. https://incrussia.ru/news/glava-mvfregulirovanie-operatsij-s-kriptovalyutamineizbezhno

Kaznacheeva, D., \& Dorosh, A. (2020). Cryptocurrency: problems of legal regulation. Cryptocurrency: problems of legal regulation. Vesnik of the Criminological Association of Ukraine, 2 (23), 171-176. http://dspace.univd.edu.ua/xmlui/handle/123 $456789 / 9575$

Law \& Trust. (2021a). Legal status of cryptocurrencies.

https://lawstrust.com/ico/pravovoj-statuskriptovalyut

Law \& Trust. (2021b). Countries with positive cryptocurrency regulation. https://lawstrust.com/ico/pravovoj-statuskriptovalyut/crypto-friendly

Pinkevich, T., \& Smolyaninov, E. (2021). International experience in countering criminal activity using cryptocurrency. Moscow: Academy of Management of the 
Ministry of Internal Affairs of Russia. ISBN 978-5-907187-60-3.

https://mvd.ru/upload/site120/folder_page/0 15/122/996/Mezhdunarodnyy_opyt.pdf

Proposition 3637, On Virtual Assets. Of the President June 11, 2020. http://w1.c1.rada.gov.ua/pls/zweb2/webproc 4_2?id=\&pf3516=3637\&skl=10

Rasheva, N.Yu., \& Chirkova, O.I. (2017). Legal foundations of electronic currency (for example, bitcoin). Management in modern systems, 1(12), 60-68. https://cyberleninka.ru/article/n/pravovyeosnovy-elektronnoy-valyuty-na-primerebitcoin

Skripnik, V. (2018). The place of cryptocurrency in the system of civil rights objects. Entrepreneurship, economy and law, 8, 64-78.

Solodovnikov, N.S., \& Bardina, P.O. (2019). New digital rights regulation. Pepeliaev group. https://www.pgplaw.ru/analytics-and- brochures/alerts/the-new-regulation-ofdigital-rights/

Soslovsky, V.G., \& Kosovsky, I.O. (2016). Cryptocurrency market as a system. Financial and credit activities: problems of theory and practice, 2 , 236-246. http://nbuv.gov.ua/UJRN/Fkd_2016_2_24

Vasilevskaya, L.Yu. (2019). Token as a new object of civil rights: problems of legal qualification of digital law. Actual problems of Russian law, 5, 113-140. https://cyberleninka.ru/article/n/token-kaknovyy-obekt-grazhdanskih-prav-problemyyuridicheskoy-kvalifikatsii-tsifrovogo-prava

Vc.ru. (2018). Attitude of countries to cryptocurrency. https://vc.ru/crypto/46298otnoshenie-stran-k-kriptovalyute

Zhelyuk, Y., \& Brecko, A. (2016). The use of cryptocolution in the payment market: new opportunities for national economies. Bulletin of Economics, 3, 50-60. http://visnykj.wunu.edu.ua/index.php/visnyk j/article/view/706 